\title{
The Necessity / Need of Strengthening the Applicative Character in the Scientific Research in Geography
}

\author{
Prof. dr. Mahir Hoti \\ "Luigj Gurakuqi" University of Shkodra \\ Dr. Majlinda Ziu \\ "Sami Frashëri" Gymnasium in Tirana
}

(Case of Albania)

Abstract

The revolution of research, precisely, the revolution of knowledge has been transforming the role of modern universities in Europe and farther. Nowadays, it is emphasized the need to revise the whole process of research-technology - production. The enhancement of human knowledge is a consequence of the changes and transformations being done in all aspects of the practical life of the society. A quick development has accompanied the direct or indirect geographical group sciences. Among the widespread fields of study introduced nowadays, it is hard to find another field of study, which is more interdisciplinary than the one being discussed. Albania is trespassing another stage of social and economical transformations, and this is due to political changes undergone in the years 1990-1991. This stage is followed by other new changes which require further scientific studies based on specific topics. An important step has been done in the regional tackling of problems, where it was estimated the interdependence between the geographic environment and the demographic and economic development of specific regions. Such studies have been done in the field of tourism, a field much explored in the aspects of natural and cultural inheritance. The scientific research in Geography needs to be developed through detailed analysis, which is based on primary and secondary data. These data should be well interpreted from a contemporary point of view, characterized also from physical and geographical transformations, as well as social and economical ones. Although the curricula of Geography in Albanian universities has undergone several changes, (a lot of subjects have been added to the curricula), their effect on the scientific research has not been so much reflected. The field of the applicative scientific research in Geography is broad, because the object of Geography is broad. The applicative scientific research of Geography in Albania will give importance to the role of the geographer, especially in different levels of decisions. The paper will show concrete arguments for the necessity of strengthening the applicative character in the scientific research of Geography in our country.

\section{Introduction}

Universities nowadays are facing big challenges. The research revolution, or the revolution of knowledge, is transforming the role of the modern universities in Europe and worldwide. Naturally it has come the need to revise the whole process involving research- technology - production.

The development and the progress of the human knowledge is a result of the development in all aspects of life. A quick development has characterized geography as well, which involves in itself physical, natural and human aspects by making geography a science with a typical interdisciplinary character.

Albania is passing through another phase of social \& economic transformations, as a consequence of the political changes happened in 1990 - 1991. The transformation is followed by a series of positive changes, nevertheless that a lot of problems are faced as well in the political, social \& economic life of the country.

This phase of transformations needs to be carried out scientific studies and researches to reflect the development happening so far and at the same time to provide solutions for different subjects, practices and fields of life. 


\section{Aspects of the applicative Geography}

The Albanian Universities and High Education in general in Albania, possess very few elements of scientific research. In our universities prevails the classic element of preparing specialists in different fields, while in relation to text-books and publications prevail the descriptive ones and not the scientific solutions. This can be clearly seen in the doctoral thesis presented lately, where the conclusions and the recommendations are generic ones with very few practical ways for solution and with little utilitarian values.

The same situation prevails in geographic studies as well, in relation to the applicative aspects. Such aspects are noticed to be few.

An indicator of such a perception is the measure taken by the Government to close down the Center of Geographic Studies by melting such a center with the University Departments of Geography, aiming at an integration of lecturing with the scientific research. As a matter of fact the expectations were not achieved.

Profiting from the world best experiences and achievements in the field of regional problems treatment, especially concerning the focus on the inter-relation features existing between the geographic, demographic and economic development of some specific regions. Such studies and scientific researches are conducted in the field of tourism, which is a potential field for our country as well based on the characteristics of Albania in different aspects of natural and cultural heritage.

There are not conducted yet basic studies from a regional perspective. For example: In the subject of 'Geography of Albania" the Physical Geography part is treated separately from the "Human Geography of Economic Aspects". As a result the Physical Geography divides Albania in four physical-geographic counties, while the "Human Geography of Economic Aspects" divides Albania into five economic regions. Some studies should be undertaken for small areas as well taking into consideration the sustainable development and its alternatives based upon the profile or the peculiarities of the zone.

Object of the geographic scientific research in Albania should be the aspects related to the high speed of urbanization of certain areas of the county, which is happening quite more fast as compared to the general rates of the growth of the population. There is not conducted any applicative research in the field of geography to explain typical examples like the growth of the urban population of Albania from $30 \%$ at the beginning of 90 ', into $52 \%$ in our days, or to treat the factors that explain why $1 / 3$ of the population of Albania lives in Tirana.

Another object of scientific research is the unusual intervention of the society in the environment by bringing as consequences the phenomena of pollution, degrading of certain areas and deforestation in relatively large zones.

Management of joint waters (rivers, lakes) is very important to be part of applicative scientific research. This is related to cross-border cooperation as an alternative of development and integration in EU. Such a cooperation is in need of applicative studies related to concrete examples like the case of Radika river in Macedonia. Radika river is part of Drinit i Zi river basin, and a branch of this river as well. The deviation of Radika river will have an impact in the hydrologic regime of Drini river. The same can be said in relation to the plans for the deviation of the upper part of Vjosa river within the Greek territory as well. If the deviation happens, it will have an impact on Vjosa river hydrologic regime given the fact that the biggest part of this river belongs to Albania.

Despite of the reactions of the social society, it is a duty of the scientific institutions and of the central decision-makers to create the proper conditions for the development of a qualitative scientific research.

In such situations it is a necessity that the scientific research should be in the guide and speak loudly despite the pragmatic and subjective attitude of the political class that is more based upon the pragmatic decisions.

Providing solution, or recommendations through suggesting alternatives should be the approach of the applicative researches. Such researches should never be focused only upon the identification of the issue, or upon giving some vague and generic recommendations. 


\section{Why applicative Geography?}

There is not a final definition for Geography in general and for the applicative Geography specifically. The applicative geography is not part only of one branch of geography. Elements of the applicative geography can be found in every field of the geographical research, including physical \& human geography. Since 1970, A. Kuhn among other things said that: "Applicative geography is always a child of its time".

Space Planning - is the main field of the application of Geography. The concept of the applicative geography includes making use of geography in resolving the space issues of the society (H. Gotz - G. Von Rohr). This is the primary field of the applicative Geography. Space Planning is not only related to the physical and natural features, or just related to geographical distribution, but it includes financial planning, human resources planning, etc. . The administrative \& territorial division of a country based upon the geographic position, on the physical and natural features, on the economic tradition and on ethnic and cultural characteristics is an example that explains the need for applicative geographic researches in Space Planning. Geography should lay down problems for solution, by offering suggestions and alternatives through applicative researches. Steps including the envisage, the evolution and the planning in relation to a certain issue/problem may be defined as applicative Geography. So the applicative Geography should be understood as an instrument that specifies the future development.

Market economy needs the use of the applicative Geography. The main conflicts in relation to space/areas are: "Economy towards ecology", "the current tendency of overpopulating some specific areas/zones", "the protection and an efficient management of the natural reserved areas", "The village going towards the city", "the mountainous and remote areas are not taken into consideration from the point of view of development, but are abandoned massively". This phenomenon is noticed in a lot of countries under development.

Examples of the need to use the applicative Geography researches can also be found a lot in the regional level. Shkodra low land region is in need of comprehensive applicative geographical researches. Such a zone suffers from frequent floods. It's a zone where the waters of Drin \& Buna rivers meet. This region "suffers" from the problems existing even in the sectors of the upper flows of these rivers. This region is characterized by some tectonic fractures, longitudinal and transverse ones, which generate earthquakes. So undertaking applicative geographic researches on the issues and problems mentioned above would be a great help for the strategic approach how to reduce or eliminate the consequences.

A quick dynamics is happening at the Adriatic seashore. The sea in some areas has progressed a lot, and in some others has gone back. Applicative geographical studies are needed to define not only the annual speed or the decade speed of the sea erosion and its direction, but it is very important to deal as well with the alternatives how to manage the situation. The geographer (specialized in geomorphology) has to play a primary role. The reasons are of a global, regional and of a local nature. Applicative researches are needed in relation to different phenomena (for example related to excavation of the riverbeds to profit construction material from them).

Applicative geographical researches are necessary to offer practical solutions in the social \& economic field as well. Such studies are more than welcomed for the mountainous zones especially related to the movements of the population and the measures for the future. In Northeastern part of Albania applicative researches with a regional character can help the state institutions to play the proper role and to undertake the necessary measures to address such a situation. Another field of applicative researches with a regional character where geography is a necessity is the construction of HEC-s (Hydro Electrical Centrals) for the production of the electric current. There were planned to build about 200 of such kind of small $\mathrm{HEC}$-s in Albania. A lot of problems coming as a consequence of the construction of such a big number of them are possible to be solved through the geographical researches, because we, the geographers, are convinced that very few of such HEC$s$ have taken into consideration their impact on the environment.

In Albania, in the working groups for Census 2011 and for the new administration \& territorial division, were not involved geographers at all. Geographers tried to write some articles in the media and to express their views in relation to the criteria used and to the decisions adopted. But there was not taken into account any geographical applicative research.

How can be treated an object of a geographic interest? A "possibility" is a "perspective". Out of this "perspective" it is defined the research methodology (Borsdorf A. ). The geographic substance has a lot of specific elements that should be described and studied according to the form and the content. 
Another field where the applicative Geography can give its contribution is the tourism in Albania and the protection of the environment. Such researches can help on practical terms how to apply the tourism offers, based upon the natural, economic and social conditions of the country. Geographers can introduce EU best practices as well in such a direction.

The scientific research in Geography is in need of becoming more applicative, by offering specific analysis, based on primary and secondary data interpreted in compliance with contemporary standards/requests, especially on issues related to the environment protection, to the social \& economic transformations causing consistent changes in the Albanian geographical areas.

The curricula of geography in the Albanian Universities has undergone a lot of changes through introducing new subjects by aiming to regulate the percentage between theory and practice, but these changes have very little included the impact of the scientific search. The research work starts since in the high school while in the University it should be applicative as well. In the German-speaking countries of Europe, about $50 \%$ of the students who study Geography in their thesis and in their Diplomas are oriented towards the so-called "Diplom Arbeit in angewandte Geographie". A lot of universities in these countries prepare new specialized geographers, especially related to space planning issues.

In Albania as well, there are some positive signs because more and more new scholars are being involved in applicative geographical research, especially by applying the new methods such as GIS, ICT, etc. This can be easily noticed from the presentations of these scholars in different national and international seminars, workshops conferences, or from their participation in different regional applicative projects.

\section{Employment of geographers}

In Albania the employment of geographers is mainly in the education sector, while their employment in the national or regional institutions is rare at a time that their applicative contribution is a necessity in the institutions responsible for:

- $\quad$ Planning of the territory;

- $\quad$ Assessment of natural and human resources;

- $\quad$ Development of tourism;

- Management and protection of environment and of the natural heritage;

- $\quad$ Data and statistics elaboration (INSTAT)

- $\quad$ Preparation of maps through GIS technology.

But geographical studies in general, in Albania, are far from being exhaustive (Laçi. S), while in some aspects such studies are still in their first steps. ${ }^{1}$

In the world there is a variety of opportunities in the Labour Market where the geographer can be employed

Geographers can apply their knowledge in practice and can give their applicative contribution in a lot of important alternatives including a lot of fields and activities such as:

Planning of the territory

- $\quad$ Planning of the territory and protection of the environment;

- $\quad$ Planning of construction and sheltering;

- $\quad$ Complementary activities in relation to space organizing.

1 "Geography and the University Geographic Education in Albania during the period 1990 - 2012" 


\section{$\underline{\text { Applicative researches }}$}

- $\quad$ Research on road trafficking, telecommunication, etc;

- $\quad$ Tourism, management of tourism, sampling;

- $\quad$ Property Market analysis and house building needs

\section{Environment and the territory}

- $\quad$ Geology, geodetics, echo-systems, echo-management, environmental economy; avalanches ;

Earth science, climatology, hydrology, measures for protection from floods, protection from

Research on risk assessment, calculation of damage costs ;

Management of protected zones.

\section{Interdisciplinary cooperation}

- Cooperation on development issues, on project management, etc. ;

- $\quad$ Cooperation with NGO-s

Management

Management of research programs (national and international ones);

Management of natural disasters consequences.

\section{Counseling}

$$
\begin{array}{ll}
- & \text { Counseling activities } \\
\text { - } & \text { Project drafting/designing } \\
\text { - } & \text { Facilitation of activities } \\
\text { - } & \text { Public relation counseling }
\end{array}
$$

Information and documentation

- $\quad$ Contribution in written and electronic Media

- $\quad$ Lecturers, text-books writers

- $\quad$ Coaching practical activities

- $\quad$ Contribution in libraries, archives offices, State Information Service, etc

\section{Exploring}

$$
\begin{aligned}
& \text { GIS and IT } \\
& \text { Cartography }
\end{aligned}
$$

Teaching \& research in education Institutions

- $\quad$ Universities, High schools, Researching Centers

- Technology implementation, cooperation between the economic activities and applicative geography researches

Scientific research process in the Universities 
- $\quad$ Data collection and project-based initiatives with public \& private professional high schools

- $\quad$ Publication activities.

(The idea is taken from Axel Borsdorf and is further elaborated)

\section{Conclusions and recommendations}

- Scientific research scope in Geography, with emphasis on the applicative forms, is very wide, as it is the objective of study of Geography as a science.

- The applied Geography can serve as a bridge linking the natural sciences with the human ones in general.

- The applied geography will introduce in Albania as well the role of the geographer in decision-making process on a lot of issues.

- Nevertheless, the applied geography in Albania is in different modest levels, so it is a necessity to develop the forms of the applicative geographical research in a lot of fields of life and scopes of activities.

- It should be aimed at the integration of the applied geographical researches into the complex and comprehensive regional and national studies through cooperation with other specialists involved in similar fields of study such as through cooperation with biologists, sociologists, climatologists, geologists, hydro-technicians, historians, economists, etc. . In general the current tradition tends more towards mono-studies, then towards cooperation and integration of studies, so comprehensive approach should be considered as the key method by geographers in order to be able to integrate their applicative studies with other projects and stakeholders

- Training and qualification activities abroad aiming at best EU practices on application of knowledge in Geography.

- Financial support is a problem that needs to be solved for the development of science in general and for the development of the applicative Geography in particular, aiming at research in the terrain, monitoring activities, integrated activities, use of modern technology, for both the Physical Geography and for the Human Geography as well.

\section{Literature}

[1] Borsdorf, Axel. Geografisch denken und wissenschaftlich arbeiten. 2. Auflage Verlag Berlin-Heidelberg, 2007.

[2] Götz, H. \& von Rohr, G. Augewandte Geographie, 2002.

[3] Hoti, Mahir. "Geography and Economy". Second National Conference of Geography, in Shkodra, 23-24 November 1995, page 4-6.

[4] Kabo, Mevlan. Albanalogy Studies IV, 2012/4, page 24-40.

[5] Laçi, Sabri. "Geography and the University Geographic Education in Albania during the period 1990 - 2012" .

[6] Qiriazi, Perikli. Albanology Studies 1999/1, page. 103-112.

[7] QSGJ, Geographical Studies 2006/17, Cross-border cooperation - alternative of EU Integration.

[8] R. Montello, Daniel \& C. Sutton, Paul. An Introduction to scientific research methods in Geography, 2006.

[9] Renber, Paul \& Pfaffenbach Carmela. Methoden der empirischen Humangeograph Westermann (das Geographisch seminar), Braunschweig 2005.

[10] Samimi, Ergjin. "Vitalization of Geography and the impact on the economy through the qualification and through the modern technology", Second National Conference of Geography, Geography and Economy. 